\title{
Evaluation of peroxide index and oxidative rancidity of broiler diets and the occurrence of breast muscle anomalies
}

Avaliação do índice de peróxido e da rancidez oxidativa de rações de frangos de corte e a ocorrência de anomalias na musculatura do peito

\author{
M. W. M. Calasans'1; T. Q. Furian²; K. A. Borges²; L. F. Santos ${ }^{3}$, C. P. Freitas 3 ; F. \\ Pilotto $^{3}$; L. R. Santos $1,3^{*}$ \\ ${ }^{1}$ Programa de Pós-Graduação em Ciência e Tecnologia de Alimentos, Universidade de Passo Fundo (UPF), $99052-$ \\ 900, Passo Fundo, RS, Brasil. \\ ${ }^{2}$ Centro de Diagnóstico e Pesquisa em Patologia Aviária, Universidade Federal do Rio Grande do Sul, 91540-000, \\ Porto Alegre, RS, Brasil. \\ ${ }_{3}^{3}$ Programa de Pós-Graduação em Bioexperimetação, Universidade de Passo Fundo (UPF), 99052-900, Passo Fundo,
} RS, Brasil.

*luruschel@upf.br

(Recebido em 13 de maio de 2020; aceito em 15 de julho de 2020)

The incidence of breast muscle anomalies, such as white striping (WS) and wooden breast (WB), has increased over the last two decades. These myopathies have different implications on the quality of poultry meat, which depending on the degree of the anomaly, may be rejected due to undesirable appearance or lower technological and nutritional characteristics. Despite the high economic impact, the causes of these myopathies have not yet been defined. The increased susceptibility of poultry to the oxidation process may influence the occurrence of hemorrhagic disorders and muscular dystrophies, necrosis, and fibrosis associated with myopathy with unknown etiology development. Coagulants such as ferric chloride (FC) used in the treatment of effluents can be involved in the feed peroxidation process. Our aim was to evaluate whether the peroxides generated by the presence of FC in poultries' diets are related to myopathies. Broilers were treated with feed supplemented with 4,8 , or $12 \mathrm{~mL} \mathrm{FC/Kg}$ of feed. The presence of WS and WB, feed peroxide indices (PI), mean weights, and feed conversion ratios were evaluated. The highest FC concentration indicated higher peroxide production. Addition of 4,8 and $12 \mathrm{~mL}$ of FC yielded $60.0 \%, 70.0 \%$, and $70.7 \%$ of myopathies, respectively, which indicated a possible relationship between food peroxidation and myopathies. Lipoperoxidation resulted in the lowest mean final weight and worsening of the feed conversion in the birds treated with $12 \mathrm{~mL}$ of FC. Feed with a high peroxide index is a factor that can increase the incidence of WB and WS.

Keywords: carcass quality; coagulants; myopathy.

A incidência de anomalias musculares no peito, como White Striping (WS) e Wooden Breast (WB), aumentou nas últimas duas décadas. Essas miopatias têm diferentes implicações na qualidade da carne de aves, que, dependendo do grau da anomalia, podem ser rejeitadas devido à aparência indesejável ou diminuição das características tecnológicas e nutricionais. Apesar do alto impacto econômico, as causas dessas miopatias ainda não foram definidas. O aumento da suscetibilidade das aves ao processo de oxidação pode influenciar a ocorrência de distúrbios hemorrágicos e distrofias musculares, necrose e fibrose associadas à miopatia com desenvolvimento etiológico desconhecido. Coagulantes como o cloreto férrico $(\mathrm{CF})$ usado no tratamento de efluentes podem estar envolvidos no processo de peroxidação da alimentação. Nosso objetivo foi avaliar se os peróxidos gerados pela presença de CF nas dietas de aves estão relacionados a miopatias. Os frangos ( $\mathrm{n}=240$ ) foram tratados com ração suplementada com 4,8 ou $12 \mathrm{~mL}$ de $\mathrm{CF} / \mathrm{kg}$ de ração. Foram avaliadas a presença de WS e WB, índices de peróxido de ração (IP), pesos médios e razões de conversão alimentar. A maior concentração de $\mathrm{CF}$ indicou maior produção de peróxido. A adição de 4, 8 e $12 \mathrm{~mL}$ de $\mathrm{CF}$ produziu $60,0 \%, 70,0 \%$ e $70,7 \%$ das miopatias, respectivamente, o que indicou uma possível relação entre peroxidação alimentar e miopatias. A peroxidação resultou no menor peso final médio e na piora da conversão alimentar nas aves tratadas com $12 \mathrm{~mL}$ de CF. A alimentação com um alto índice de peróxido é um fator que pode aumentar a incidência de WB e WS.

Palavras-chave: qualidade de carcaça; coagulantes; miopatia. 


\section{INTRODUCTION}

Improvements in poultry production within the past 50 years have led to increased muscle yield and growth rate, which may be contributing to development of new muscle disorders in chickens, such as myopathies of idiopathic origin [1]. The incidence of breast muscle anomalies such as deep pectoral myopathy (DPM), dorsal cranial myopathy (DCM), white striping (WS), and wooden breast (WB) has increased over the last two decades $[2,3,4,5]$. Some industry reports suggest up to $20 \%$ WB occurrence in fast growing heavy broilers with an estimated cost of more than US $\$ 500$ million/year to the US industry alone [5]. Myopathy has different implications on the quality of chicken meat. Depending on the degree of the anomaly, it may be rejected due to undesirable appearance or lower technological and nutritional characteristics [1, 2, 3, 4]. The meat affected by WB and WS exhibit poorer nutritional value, harder texture, and impaired water-holding capacity [6]. These myopathies led to increased carbonylation levels and more intense proteolytic processes [7].

The WS lesion is macroscopically characterized by white parallel striations in the same direction of the muscle fibers, visible on the ventral surface of the muscle, and usually present in the major pectoral muscles [8]. It is known that the incidence of WS is higher in broilers with high breast yield, in males with high growth rates, and in flocks receiving a high energy diet [9]. The WB lesion is characterized by a hardening of the breast muscle typically in the proximal region, which may also present whiteness, hemorrhage, and surface exudate [10]. Histologically, both conditions have been characterized with myodegeneration and necrosis, fibrosis, lipidosis, and regenerative changes [8]

Despite the high economic impact, the causes of these myopathies have not yet been defined and their etiology is associated to multiple causative factors (genetics, muscle growth and development, management) [11]. One of the possible predisposing factors is bird nutrition, which has undergone changes over time in order to promote greater weight gain [10]. In order to add energetic value to the feed, oils and unsaturated fats are used as ingredients in the preparation of the broiler poultries' diets. However, the fatty acids present in these oils have chemical structures susceptible to the peroxidation process. The peroxidation can be facilitated by high oxygen concentration, moisture, heat, metal presence, and lipoxygenases $[12,13]$. The peroxidation of unsaturated fatty acids can cause inactivation of liposoluble vitamins and minerals in addition to degradation of amino acids and lipids in the muscular tissues, mainly within the pectoral region [14]. The presence of peroxyl radicals resulting from ingestion reduces the concentration of $\alpha$-tocopherol observed in tissues [15, $16]$.

The increased susceptibility of poultry to the oxidation process may influence the occurrence of hemorrhagic disorders and muscular necrosis, and fibrosis associated with myopathy with unknown etiology development. Gene selection for further development of the breast musculature accompanied by rapid growth rates made chickens particularly susceptible to oxidative stress [17]. In addition, the production of birds in warm weather and the supply of oxidized food accelerate oxidative stress in vivo [18].

Visceral oil used in the production of poultry feed is a secondary product obtained from processing in slaughterhouses, including the extraction of the oil present in effluents. Ferric chloride (FC) is one of the most common coagulants used in the treatment of effluents generated in slaughterhouses [19]. These effluents have high values of biochemical oxygen demand (BOD) and suspended solids [20]. Therefore, inorganic compounds, such as FC, eliminate phosphates, reduce the number of suspended solids, BOD, and fetid odors [21]. However, the excess of chemical compounds does not participate in the coagulation reaction and remains as a solution, which can cause cross contamination of the viscera oil. This excess coagulant may be associated with the peroxidation process in the feed. It is possible that feeding animals with oxidized fat would aggravate or accelerate the onset of the myopathy in animals already predisposed to the pathology owing to the fast growth $[22,23]$. In this context, the aim of this study was to evaluate if the consumption of feed with peroxides generated by the presence of FC is related to the cases of WB and WS in broilers. 


\section{MATERIALS AND METHODS}

This study was conducted with the formal approval of Ethics Committee on the Use of Animals of the Universidade de Passo Fundo (UPF), under registry number 016/2015.

\subsection{Birds and Experimental Design}

A total of 240 one-day-old slow-feathering Cobb, male broiler, vaccinated for infectious bronchitis, Marek's and Gumboro's disease at the hatchery were randomly placed into 16 boxes (1.5 $\times 1 \mathrm{~m} ; 10$ birds $/ \mathrm{m}^{2}, 15$ birds each box) without being previously weighed. Water and feed were offered ad libitum, and the environmental temperature was set to provide physiological comfort. Four treatments with four replicates each were performed after considering the standard deviation of the variable responses of the study. The birds were fed commercial diets with specific formulations according to nutritional requirements for age [24]. The animals were weighed at $13^{\text {th }}$ day and were distributed in the boxes according to the average weight obtained. From the $13^{\text {th }}$ to the $49^{\text {th }}$ day of age, the birds were fed diets added with different concentrations of ferric chloride (FC): (1) without addition of FC (Treatment 1); (2) $4 \mathrm{~mL}$ of FC/Kg of feed (Treatment 2); (3) $8 \mathrm{~mL}$ of $\mathrm{FC} / \mathrm{Kg}$ of feed (Treatment 3); and (4) $12 \mathrm{~mL}$ of $\mathrm{FC} / \mathrm{Kg}$ of feed (Treatment 4). The inoculation of ferric chloride in the feed was carried out five days before consumption. The animals were weighed every week, and the final mean weight and feed conversion obtained in each treatment were measured.

\subsection{Peroxide Index in Feed}

The physicochemical analyses to determine the feed peroxide index (PI) were carried five days after the addition of FC and prior to bird breeding, and these analyses were repeated weekly as described by Zenebon et al. (2008) [25]. Due to the strongly oxidizing action, the organic peroxides formed at the beginning of the rancidification process act on the release of iodine from the potassium iodide compound. The iodine is titrated with addition of sodium thiosulfate in the presence of the starch as indicator [26]. To determine the PI, 1g of lipid extracted from the sample in a flat bottom flask was used. Thirty milliliters of acetic acid and chloroform in a 3:2 ratio were added, and the sample was homogenized until it had dissolved. Subsequently, $0.5 \mathrm{~mL}$ of the saturated potassium iodide solution was added, and the solution was kept away from the light for 1 min after which $30 \mathrm{~mL}$ of distilled water and $0.5 \mathrm{~mL}$ of indicator starch were added, and the peroxide level was titrated with sodium thiosulfate solution [25].

\subsection{Oxidative Rancidity in Feed}

A Kreis Test was performed as previously described [25, 27] in order to evaluate oxidative rancidity in feed, which may cause odor and taste changes of oils and fats due to the decomposition of peroxides and formations of secondary compounds such as aldehydes. Five milliliters of molten substance from the feed were transferred to a beaker. Five milliliters of hydrochloric acid were added, and the material was homogenized for $30 \mathrm{sec}$. Five milliliters of the $0.1 \%$ phloroglucinol solution were then added. The material was shaken again for $30 \mathrm{sec}$, and the reaction was left to stand for $10 \mathrm{~min}$. In the presence of rancid and acidic substances, phloroglucinol reacts with the oxidized triglycerides, resulting in a pink or red coloration, the intensity of which increases with deterioration due to the presence of aldehydes originating from the secondary oxidation.

\subsection{Detection of WS and WB}

The chickens were slaughtered at 49 days of age in a slaughterhouse under the supervision of the Federal Inspection Service. The carcasses from the experiment were separated during the evisceration process and were evaluated macroscopically for the presence or absence of WS and WB by trained professionals in the Department of Final Inspection. The carcasses were classified according to the type of injury in the pectoralis major muscle following characterization standards previously described in the literature $[28,29,30]$. Breasts were classified as normal when no 
hardness and paleness areas (WB) or no distinct white lines (WS) were observed. The macroscopic lesions observed externally were confirmed by cutting the pectoralis major muscle.

\subsection{Statistical Analysis}

Data were subjected to statistical analysis using the PASW Statistic software (IBM ${ }^{\circledR}$, Hong Kong). Descriptive statistics were used to determine the relative frequency of myopathy detection and for the determination of the means and the standard deviations of the zootechnical indices and the PI of the feed. For the comparison of the means of the indices, the parametric test, ANOVA and the Tukey test were used. The non-parametric chi-squared $(\chi 2)$ test was used to compare myopathy detection among treatments. Significance was defined as $p<0.05$.

\section{RESULTS AND DISCUSSION}

The Table 1 shows the peroxide index (PI) observed in the feed according to the administered FC concentration.

Table 1 - Mean peroxide index and relative frequency of white striping and wooden breast in 49-day old broiler carcasses submitted to different treatments with addition of ferric chloride $(F C)$ to the feed.

\begin{tabular}{ccc}
\hline Treatment & $\begin{array}{c}\text { Mean peroxide index } \\
(\mathbf{m e q} / \mathbf{k g})^{*}\end{array}$ & $\begin{array}{c}\text { Relative freq } \\
\text { of myopathie }\end{array}$ \\
\hline Control & $3.41 \pm 1.14^{\mathrm{a}}$ & $54.9^{\mathrm{a}}$ \\
$\mathbf{4} \mathbf{~} \mathbf{L}$ of $\mathbf{~} \mathbf{C} / \mathbf{K g}$ & $14.63 \pm 11.38^{\mathrm{b}}$ & $60.0^{\mathrm{a}, \mathrm{b}}$ \\
$\mathbf{8} \mathbf{~} \mathbf{L}$ of $\mathbf{~ F C / K g}$ & $22.89 \pm 9.9^{\mathrm{b}}$ & $70.0^{\mathrm{b}}$ \\
$\mathbf{1 2} \mathbf{~} \mathbf{L}$ of $\mathbf{~ F C / K g}$ & $37.03 \pm 16.16^{\mathrm{c}}$ & $70.7^{\mathrm{b}}$ \\
\hline
\end{tabular}

Different letters in the same column indicate significant difference by Tukey test (peroxide index) or chisquared test (myopathies frequency) $(p<0.05)$. meq $=$ milliequivalent. ${ }^{*}$ Tolerance of peroxide in feed for broiler chickens $=4 \mathrm{meq} / \mathrm{kg}$.

Increases in peroxide levels according to storage time have been reported in studies evaluating meat flour, corn, and cashew nut samples [31, 32, 33]. In the present study, treatments $2(4 \mathrm{~mL}$ $\mathrm{FC} / \mathrm{Kg}), 3(8 \mathrm{~mL} \mathrm{FC} / \mathrm{Kg})$ and $4(12 \mathrm{~mL} \mathrm{FC} / \mathrm{Kg})$ presented a higher peroxide index in relation to the treatment 1 (control). However, it was not observed a progressive increase in peroxide production, since there was no significant difference ( $p>0.05$ ) between treatments 2 and 3. Foods with high lipid content are more susceptible to oxidation [34]. The PI is an analytical determination for evaluating the oxidation state of fats (rancidity), which is defined as the measurement of the reactive oxygen content and measured in milliequivalents of oxygen per $1000 \mathrm{~g}$ of lipid [35]. Even without addition of FC, PI in the feed was close to $4 \mathrm{meq} / \mathrm{Kg}$, a tolerance level generally accepted for broiler chickens [36], probably due to the high amount of unsaturated fat in composition of the diet.

Regarding the occurrence of myopathies according to the treatments (Table 1), it is observed that the similarity observed in the PI also reflected in the occurrence of myopathies. The addition of FC resulted in a significant $(\mathrm{p}<0.05)$ increase of these lesions for treatments $3(8 \mathrm{~mL} \mathrm{FC} / \mathrm{Kg})$ and $4(12 \mathrm{~mL} \mathrm{FC} / \mathrm{Kg}$ ) in relation to treatment 1 (control). However, there was no difference (p>0.05) in the occurrence of myopathies among treatments 2,3 and 4 . In addition, there is no significant difference $(\mathrm{p}>0.05)$ between the treatment $2(4 \mathrm{~mL} \mathrm{FC} / \mathrm{Kg})$ and the control. These results indicate that there is a possible relationship between food peroxidation and the development of these myopathies.

Table 2 describes the lesions found for each treatment. Four birds naturally died during the experimental period and 22 seals were broken, leaving a total of 214 analysed carcasses. From the analysed carcasses, 64.01\% (137/214) presented myopathies. From affected muscles, 18.25\% (25/137) presented only WS, $11.68 \%$ (16/137) only WB, and in 70.07\% (96/137) both lesions were detected. The results showed a significant association of the presence of both lesions in the same carcass $(\mathrm{p}<0.05)$. The concomitant presence of WB and WS is often observed at macroscopic evaluation of carcasses $[6,37]$. 
Table 2 - Relative (\%) frequencies of white striping (WS) and wooden breast (WB) in 49-day old broiler carcasses submitted to different treatments with addition of ferric chloride $(F C)$ to the feed.

\begin{tabular}{cccc}
\hline Treatment & WS & WB & WS + WB \\
\hline Control & $7.84^{\mathrm{a}}$ & $3.92^{\mathrm{a}}$ & $43.14^{\mathrm{ab}}$ \\
$\mathbf{4} \mathbf{~} \mathbf{L}$ of $\mathbf{F C} / \mathbf{K g}$ & $21.82^{\mathrm{b}}$ & $32.73^{\mathrm{a}, \mathrm{b}}$ & $5.45^{\mathrm{a}, \mathrm{b}}$ \\
$\mathbf{8} \mathbf{~} \mathbf{L}$ of $\mathbf{F C} / \mathbf{K g}$ & $6.00^{\mathrm{a}}$ & $8.00^{\mathrm{a}, \mathrm{b}}$ & $56.00^{\mathrm{a}}$ \\
$\mathbf{1 2} \mathbf{~} \mathbf{L}$ of $\mathbf{F C} / \mathbf{K g}$ & $10.34^{\mathrm{a}, \mathrm{b}}$ & $12.07^{\mathrm{b}}$ & $48.28^{\mathrm{a}}$
\end{tabular}

Different letters in the same column indicate significant difference by Chi-squared test ( $p<0.05$ ).

Carcasses with WS showed muscle hypertrophy and stiffness and macroscopically exhibited whitish striations parallel to the muscle fibers and visible on the muscle surface. WB was characterized by hardness or paleness areas and, in some cases, haemorrhagic lesions, increased volume, and the presence of yellow fluid on the muscle surface. The macroscopic lesions observed were similar to those previously described $[8,38]$. However, it is important to note that the initial or discrete lesions can be interpreted as normal pectoral muscles, even by trained professionals, found in commercial slaughterhouses [30]. These lesions share similar histopathological changes, characterized by infiltration of inflammatory cells, necrosis of muscle fibers, lower capillary densities, and variabilities in fiber size [39]. Some authors suggest that WB may correspond to the evolution of WS cases $[17,40]$. The presence of oxidation metabolites in muscles affected by WB and by WS shows that accelerated growth factors affect vascular and muscular development, indicating that the peroxide and free radical formation in the diet is an additional cause that could accelerate the occurrence of these lesions [40].

The action of oxidative stress as a trigger agent of myopathy in broilers has recently been described by Abasht et al. (2016) [40] and Sundekilde et al. (2017) [41], who verified the occurrence of WB associated with a significantly lower content of antioxidants such as anserine and carnosine. The presence of peroxide in the feed in actives amino acids and nutrients that have antioxidant actions and it may be possible that it also affects the levels of carnosine, anserine, and creatine in the muscle of the animals [40, 41]. In addition, chicken meat is traditionally recognized as highly sensitive to the oxidative process due to the higher level of muscle lipid unsaturation [42]. The evaluation of secondary oxidation products obtained via the Kreis test presented negative results in all analyses. Peroxides, which are primary oxidation products, are unstable intermediates, especially at high temperatures or in the presence of transition metals [22]. During their decomposition, secondary compounds of diverse nature as aldehydes, ketones, hydroxy acids, hydrocarbons, and polymers are produced and generally result in unpleasant odors $[12,27]$. The absence of this type of oxidation in the analyses indicates that the feed did not present advanced degradation and that primary oxidation and free radicals are associated with myopathies.

Table 3 shows the mean weights and feed conversion of birds receiving different treatments with addition of ferric chloride.

Table 3 - Mean weight and feed conversion of 49-day-old broilers submitted to different treatments with addition of ferric chloride (FC) to the feed.

\begin{tabular}{ccc}
\hline Treatment & Mean weight $(\mathbf{g})$ & Feed conversion \\
\hline Control & $3,691 \pm 0.35^{\mathrm{a}}$ & $1.59^{\mathrm{a}}$ \\
$\mathbf{4} \mathbf{~} \mathbf{L}$ of $\mathbf{~ F C / k g}$ & $3,658 \pm 0.31^{\mathrm{a}}$ & $1.64^{\mathrm{a}}$ \\
$\mathbf{8} \mathbf{~} \mathbf{L}$ of $\mathbf{~ F C / k g}$ & $3,622 \pm 0.28^{\mathrm{a}}$ & $1.64^{\mathrm{a}}$ \\
$\mathbf{1 2} \mathbf{~} \mathbf{L}$ of $\mathbf{~ F C / k g}$ & $3,381 \pm 0.42^{\mathrm{b}}$ & $1.75^{\mathrm{b}}$ \\
\hline
\end{tabular}

Different letters in the same column indicate significant difference by Tukey test ( $p<0.05)$. 
Feed consumption can be influenced by several factors, especially the dietary energy level and the palatability $[12,33]$. In this study, the presence of substances generated from the oxidative process that negatively interferes in the taste and odor of the feed was not observed. However, the lipoperoxidation process, which decreases the energy value of the food due to the destruction of fatty acids $[33,43]$, resulted in the lowest mean of final weight and a higher feed conversion of the treated birds with $12 \mathrm{~mL} \mathrm{FC/Kg}$. This diet had an average peroxide index of $37.03 \mathrm{meq} / \mathrm{Kg}$. Although oxidative stress resulted in biological damage and interfered in bird growth in a negative effect [44], no significant differences were observed in the final weight and feed conversion among the other treatments with a mean PI of 14.63 and $22.89 \mathrm{meq} / \mathrm{Kg}$ and the control group. Likewise, Engberg et al. (1996) [43] did not observe alteration of the feed conversion in 10-day-old broilers fed diets with $17 \mathrm{meq} / \mathrm{Kg}$.

Although the mean PI differed among some treatments, other factors probably influenced the results. In this context, we highlight the accelerated weight gain and the age of the birds [37,39] In the study by Sihvo et al. (2017) [45], it was observed that the first reported cases of WB were characterized by focal lesions in 18-day-old birds. In the subsequent age groups, WB occurred in $48 \%$ to $73 \%$ of the birds, and lesions were generally diffuse and rigid. Likewise, we found preliminary results in which WS and WB were significantly less frequent in birds kept up to 42 day receiving treatments with and without $\mathrm{FC}$ addition to their feed. In that case, treatments with no FC addition, with $4 \mathrm{~mL}$ and $8 \mathrm{~mL}$ of $\mathrm{FC} / \mathrm{Kg}$ showed $32.00 \%, 48.93 \%$ and $57.77 \%$ of birds with myopathies, respectively (data not shown).

Therefore, some nutritional strategies are cited as attempts to reduce the incidence and severity of myopathy in broilers. In relation to the lesions caused by oxidative stress that was observed in this study, previous studies suggest the reduction of the polyunsaturated lipid concentration in tissues through modifications in the lipid composition of the feed and with the supplementation of $\alpha$-tocopherol and ascorbate or in combination with other elements such as selenium and vitamin $\mathrm{E}$ with potential antioxidant activity [15, 46, 47]. However, increasing levels of selenium supplementation to the diet can also increase the birds' weight gain, and consequently favor the appearance of myopathies [48]. Thus, careful storage, formulation, and cross-contamination of viscera oils used for the production of feed are factors that should be considered in order to reduce the incidence of these emerging myopathies and may be evaluate in the future by our group.

\section{CONCLUSION}

The causes of WB and WS have not yet been elucidated and their etiology is probably linked to multiple causative factors. We observed that feed supplemented with FC presented an increase in the frequency of lesions, with a significant difference of treatments with 8 and $12 \mathrm{~mL}$ of $\mathrm{FC} / \mathrm{Kg}$ in relation to the control. These results indicate that a high feed peroxide index is a factor that can increase the incidence of breast muscle anomalies, such as WS and WB.

\section{REFERENCES}

1. Mutryn MF, Brannick EM, Fu W, Lee WR, Abasht B. Characterization of a novel chicken muscle disorder through differential gene expression and pathway analysis using RNA-sequencing. BMC Genomics. 2015 May;16:399, doi.org/10.1186/s12864-015-1623-0

2. Kijowski J, Kupinska E, Stangierski J, Tomaszewska-Gras J, Szablewski T. Paradigm of deep pectoral myopathy in broiler chickens. World's Poultry Sci J. 2014 Feb;70(1):125-138, doi:10.1017/S0043933914000117

3. Lorenzi M, Mudalal S, Claudio C, Petracci M. Incidence of white striping under commercial conditions in medium and heavy broiler chickens in Italy. J Appl Poultry Res. 2014 Dec;23(4):754-758, doi: 10.3382/japr.2014-00968

4. Petracci M, Mudala S, Soglia F, Cavani C. Meat quality in fast-growing broiler chickens. World's Poultry Sci J. 2015 Jun;71(2):363-374, doi: 10.1017/S0043933915000367

5. Barbut S. Recent myopathies in broiler's breast meat fillets. World's Poultry Sci J. 2019 May;5(4):559582, doi:10.1017/S0043933919000436 
6. Soglia F, Mudalal S, Babini E, Nunzio M Di, Mazzoni M, Sirri F, Cavani C, Petracci M. Histology, Composition, and Quality Traits of Chicken Pectoralis Major Muscle Affected by Wooden Breast Abnormality. Poultry Sci. 2016 Mar;95(3):651-9, doi: 10.3382/ps/pev353

7. Baldi G, Soglia F, Mazzoni M, Sirri F, Canonico L, Babini E, Laghi L, Cavani C, Petracci M. Implications of white striping and spaghetti meat abnormalities on meat quality and histological features in broilers. Anim. 2018 Jan;12(1):164-173, doi: 10.1017/S1751731117001069

8. Kuttappan VA, Hargis BM, Owens CM. White Striping and Woody Breast Myopathies in the Modern Poultry Industry: A Review. Poultry Sci. 2016 Nov;95(11):2724-2733, doi: 10.3382/ps/pew216F

9. Kuttappan VA, Huff GR, Huff WE, Hargis BM, Apple JK, Coon C, Owens CM. Comparison of hematologic and serologic profiles of broiler birds with normal and severe degrees of white striping in breast fillets. Poultry Sci. 2013 Feb;92(2):339-45, doi: 10.3382/ps.2012-02647

10. Bailey RA, Watson KA, Bilgili SF, Avendano S. The genetic basis of pectoralis major myopathies in modern broiler chicken lines. Poultry Sci. 2015 Dec;94(12):2870-9, doi: 10.3382/ps/pev304

11. Lilburn MS, Griffin JR, Wick M. From muscle to food: oxidative challenges and developmental anomalies in poultry breast muscle. Poultry Sci. 2019 Oct;98(10):4255-4260, doi: 10.3382/ps/pey409

12. Racanicci AMC, Menten JFM, Regitano-D'Arce MAB, Gaiotto JB, Longo FA, Pedroso AA, Sorbara JOB. Oxidação lipídica do óleo de vísceras de aves para redução de seu conteúdo de energia metabolizável para frangos de corte na fase de crescimento. Rev Bras Zoot. 2004 Set;33(4):919-923, doi: 10.1590/S1516-35982004000400012

13. Chmiel M, Roszko M, Adamczak L, Florowski T, Pietrzak D. Influence of storage and packaging method on chicken breast meat chemical composition and fat oxidation. Poultry Sci. 2019 June;98(6):2679-2690, doi: $10.3382 /$ ps/pez029

14. Racanicci AMC, Menten JFM, Regitano-D'Arce MAB, Pino LM. Efeito do uso de óleo de vísceras de aves oxidado na ração de frangos de corte sobre o desempenho, a composição da carcaça e a estabilidade oxidativa da carne da sobrecoxa. Rev Bras Zoot. 2008 Set;37(3):443-449, doi: 10.1590/S151635982008000300009

15. Panda AK, Cherian G. Role of vitamin E in counteracting oxidative stress in poultry. Poultry Sci. 2014 Nov;51(2):109-117, doi.org/10.2141/jpsa.0130134

16. Kurutas EB. The importance of antioxidants which play the role in cellular response against oxidative/nitrosative stress: current state. Nutr J. 2016 Jul;15(71):1-22, doi: 10.1186/s12937-016-0186-5

17. Sihvo HK, Immonen K, Puolanne E. Myodegeneration with fibrosis and regeneration in the pectoralis major muscle of broilers. Vet Pathol. 2014 May;51(3):619-623, doi: 10.1177/0300985813497488

18. Zhang W, Xiao S, Lee EJ, Ahn DU. Consumption of oxidized oil increases oxidative stress in broilers and affects the quality of breast meat. J Agric Food Chem. 2011 Feb;59(3):969-74, doi: $10.1021 /$ jf102918z

19. Schoenhals M, Rennio FS, Humberto JJ. Avaliação da eficiência do processo de coagulação/flotação aplicado como tratamento primário de efluentes de abatedouro de frangos. Eng Amb. 2006 July;3(2):524.

20. Dornelles F. Análise da gestão dos tratamentos dos efluentes gerados nos abatedouros de bovinos de São Luiz Gonzaga. [Dissertation]. Santa Maria (RS): Universidade Federal de Santa Maria; 2009. 103 p.

21. Magnan RB. Análise da viabilidade técnica e financeira da substituição do coagulante cloreto férrico por policloreto de alumínio durante o processo físico-químico no tratamento de efluente de abatedouro avícola. [completion of course work]. Passo Fundo: Universidade de Passo Fundo; 2010. 54 p.

22. Estevez M. Oxidative damage to poultry: from farm to fork. Poultry Sci. 2015 Jun;94(6):1368-78, doi: $10.3382 / \mathrm{ps} / \mathrm{pev094}$

23. Petracci M, Soglia F, Madruga M, Carvalho L, Ida E, Estévez M. Wooden-Breast, White Striping, and spaghetti meat: causes, consequences and consumer perception of emerging broiler meat abnormalities. Compr. Rev Food Sci Food Saf. 2019 Feb;18:565-593, doi: 10.1111/1541-4337.12431

24. Rostagno H, Albino L, Donzele J, Gomes PC, Oliveira RF, Lopes DC, Ferreira AS, Barreto SLT. Tabelas Brasileiras Para Aves e Suínos: Composição de Alimentos e Exigências Nutricionais. 2 ed. Viçosa: Universidade Federal de Viçosa. 2011.

25. Zenebon O, Pascuet NS, Tiglea P. Métodos Físico-Químicos para Análise de Alimentos. 4 ed. São Paulo: Instituto Adolfo Lutz. 2008.

26. Mathias S.P, Rosenthal A, Gaspar A, Deliza R, Slongo AP, Vicente J, Masson LM, Barbosa C. Alterações oxidativas (cor e lipídios) em presunto de peru tratado por alta pressão hidrostática (APH). Ciênc Tecnol Alimentos. 2010 Dec;30(4):852-857, doi: 10.1590/S0101-20612010000400003

27. Silva FAM, Borges MFM, Ferreira MA. Métodos para avaliação do grau de oxidação lipídica e da capacidade antioxidante. Quím Nova. 1999 Jan/Feb;22(1):94-103, doi: 10.1590/S010040421999000100016 
28. Kuttappan VA, Lee YS, Erf GF, Meullenet JF, McKee SR, Owens CM. Consumer acceptance of visual appearance of broiler breast meat with varying degrees of white striping. Poultry Sci. 2012 May;91(5):1240-7, doi: 10.3382/ps.2011-01947

29. Teixeira, STF. Caracterização anátomo-patológica do músculo pectoralis major de frangos de corte acometidos com White Striping e Wooden Breast. [Dissertation]. Passo Fundo (RS). Universidade de Passo Fundo; 2015. 70 p.

30. Cruz RF, Vieira SL, Kindlein L, Kipper M, Cemin HS, Rauber SM. Occurrence of white striping and wooden breast in broilers fed grower and finisher diets with increasing lysine levels. Poultry Sci. 2017 Feb;96(2):501-510, doi: 10.3382/ps/pew310.

31. Racanicci AMC, Menten JFM, Iafigliola MC, Gaiotto JB, Pedroso AA. Efeito da adição do antioxidante BHT e do armazenamento sobre a qualidade da farinha de carne e ossos para frangos de corte. Rev Bras Ciênc Avícola. 2000 May/Aug;2(2):155-161, doi: 10.1590/S1516-635X2000000200005

32. Fischer G, Bermudez VL, Siqueira EB, Del Pino FAB, Anciuti MA, Maier JC, Rutz F. Peroxidação em amostras de milho, protegidas ou não por etoxiquim. Ciênc Anim Bras. 2005 Oct/Dec;6(4):227-232.

33. Lopes IRV, Fuentes MFF, Freitas ER, da Silva RB, Lima RC, Bezerra RM. Desempenho e características de carcaça de frangos de corte alimentados com rações contendo farelo da castanha de caju tratado ou não com antioxidante. Rev Bras Zootec. 2009 Aug; 38(8):1502-1508, doi: 10.1590/S151635982009000800014

34. Amaral AB, Viana SM, Lannes SCS. Lipid oxidation in meat: mechanisms and protective factors - a review. Food SciTechnol. 2018;38(1):1-15, doi: 10.1590/fst.32518

35. Ribeiro EP, Seravalli EAG. Química de Alimentos. 1 ed. São Paulo: Edgard Blücler - Instituto Mauá de Tecnologia. 2004. 196 p.

36. Cabel MC, Waldroup PW, Shermer WD, Calabotta DF. Effects of ethoxyquin feed preservative and peroxide level on broiler performance. Poultry Sci. 1988 Dec;67(12):1725-1730, doi: 10.3382/ps.0671725

37. Trocino A, Piccirillo A, Birolo M, Radaelli G, Bertotto D, Filiou E, Petracci M, XiccatoG. Effect of genotype, gender and feed restriction on growth, meat quality and the occurrence of white striping and wooden breast in broiler chickens. Poultry Sci. 2015 Dec;94(12):2996-3004, doi: 10.3382/ps/pev296

38. Velleman SG, Clark DL. Histopathologic and myogenic gene expression changes associated with wooden breast in broiler breast muscles. Avian Dis. 2015 Sep;59:410-418, doi: 10.1637/11097-042015-Reg.1

39. Radaelli G, Piccirillo A, Birolo M, Bertotto D, Gratta F, Ballarin C, Vascellari M, Xiccato G, Trocino A. Effect of age on the occurrence of muscle fiberdegeneration associated with myopathies in broiler chickens submitted to feed restriction. Poultry Sci. 2017 Feb;96(2):309-319, doi: 10.3382/ps/pew270.

40. Abasht B, Mutryn MF, Michalek RD, Lee WR. Oxidative stress and metabolic perturbations in wooden breast disorder in chickens. PLoS One. 2016 Apr;11(4):e0153750, doi: 10.1371/journal.pone.0153750

41. Sundekilde UK, Rasmussen MK, Young JF, Bertram HC. High resolution magic angle spinning NMR spectroscopy reveals that pectoralis muscle dystrophy in chicken is associated with reduced muscle content of anserine and carnosine. Food Chem. 2017 Feb;15;217:151-154, doi: 10.1016/j.foodchem.2016.08.104.

42. Min B, Nam KC, Cordray J, Ahn DU. Endogenous factors affecting oxidative stability of beef loin, pork loin, and chicken breast and thigh meats. J Food Sci. 2008 Aug;73(6):C439-C446, doi: 10.1111/j.17503841.2008.00805.x

43. Engberg RM, Lauridsen C, Jensen SK, Jakobsen K. Inclusion of oxidized vegetable oil in broiler diets. Its influence on nutrient balance and on the antioxidative status of broilers. Poultry Sci. 1996 Aug;75(8):1003-1011, doi: 10.3382/ps.0751003

44. Fellenberg MA, Speisky H. Antioxidants: their effects on broiler oxidative stress and its meat oxidative stability. World's Poultry Sci J. 2006 Mar;62(1):53-70, doi: 10.1079/WPS200584

45. Sihvo HK, Linden J, Airas N, Immonen K, Valaja J, Puolanne E. Wooden breast myodegeneration of pectoralis major muscle over the growth period in broilers. Veter Pathol. 2017 Jan;54(1):119-128, doi: $10.1177 / 0300985816658099$.

46. Xiao S, Zhang WG, Lee EJ, Ma CW, Ahn DU. Effects of diet, packaging, and irradiation on protein oxidation, lipid oxidation, and color of raw broiler thigh meat during refrigerated storage. Poultry Sci. 2011 Jun;90(6):1348-57, doi: 10.3382/ps.2010-01244.

47. Skřivan M, Marounek M, Englmaierová M, Skřivanová E. Influence of dietary vitamin C and selenium, alone and in combination, on the composition and oxidative stability of meat of broilers. Food Chem. 2012 Feb;130(3):660-664, doi: 10.1016/j.foodchem.2011.07.103

48. Cemin HS, Vieira SL, Stefanello C, Kindlein L, Ferreira TZ, Fireman AK. Broiler responses to increasing selenium supplementation using Zn-L-selenomethionine with special attention to breast myopathies. Poultry Sci. 2018 May;97(5):1832-1840, doi: 10.3382/ps/pey001 